\title{
Evaluation and Improvement Ways of Ecological State in Agroecosystems of Voghjaberd Community
}

\author{
M.H. Galstyan, L.G. Matevosyan, A.L. Mkrtchyan, M.A. Markosyan \\ Armenian National Agrarian University \\ galstyan.merujan@mail.ru, lusnyak.matevosyan81@mail.ru, a.1.m.2012@mail.ru, marine.markosyan@inbox.ru
}

\section{A R T I C L E I N F O}

\section{Keywords:}

agroecosystem,

landslide,

soil erosion,

economic and ecological assessment, reclamation

\begin{abstract}
A B S T RA C T
The disturbance of equilibrium in agroecological systems of Voghjaberd community and their productivity decrease are mainly due to the strong landslides occurred in that area and to the erodibility of land resources. In the mentioned community 500 ha land area is highly prone to landslides, while 200 and 380 ha land areas are averagely and slightly susceptible to landslides respectively. About $69 \%$ of the agricultural lands are strongly and averagely eroded.

Thus, in the landslide areas it is necessary to establish anti-landslide forest strips, while to mitigate erosion in the steep slopes it is necessary to implement perennial plant sowing and fertilization with organic fertilizers in the arable lands and rangelands.
\end{abstract}

\section{Introduction}

The imminent hazards to almost all natural and social systems of the globe are directly and indirectly related to the natural and anthropogenic factors. Biodiversity loss and negative environmental phenomena (soil erosion, landslides, chemical pulltion, etc.) sometimes irreversibly affect the productivity of natural and agricultural systems. The productivity of agroecosystems mainly depends on the soil fertility - the main resource of the mentioned system - which is considerably affected by various natural and anthropogenic factors the latter becoming the determinants of the soil productivity level (Biodiversity of Armenia, 2008, Statistical Yearbook of Armenia, 2017). In this regard the community of Voghjaberd in the Kotayk region is in an extremely unfavorable condition, where landslide and erosion processes are continuously taking place, which have rather adverse effects on the agricultural productivity: the yield capacity of the cultivated crops and fruit trees are decreasing year by year, the areas of natural pastures are subjected to degradation and the animals' productivity drops down.

The results of the latest (2015) reserach works conducted by the Geological Institute of National Academy of Sciences of Armenia have proved that the community of Voghjaberd is a landslide territory occupying 500 ha land area very much prone to landslides, also 200 and 380 ha lands, which are respectively mid and less prone to landslides; besides, these areas are developed into the clayish ground and 
without any anti-lanslide measures, the consequences can be catastrophic (Galstyan and Mkrtchyan, 2013, Economic Research in the Kotayk Region, 2005, The Nature of Armenia, 2006, Environment and Natural Resources in the RA, 2016, Analysis of Socio-Economic State of the RA Kotayk Region, 2011).

Hence, any study aimed at the productivity increase of the community agroecosystems and sustainability provision, is quite actual and stems from the requirements of the developed strategy on the agricultural and environmental productivity increase of the mentioned community.

\section{Materials and methods}

The agricultural systems of Voghjaberd community in the province of Abovyan, have been significantly affected by the natural and anthropogenic factors. To this end, we have set a task to investigate the structure of the community agroecosystems, the current state of their productivity, as well as the landslide and erosion processes peculiar to the community, at the same time developing a system of agricultural measures to be taken for the improvement of the ecological state in the mentioned environment and for the increase of agrocenosis productivity.

The studies have been conducted based on the analyses of field, visual, cartographic and production indices as well as upon the results of laboratory, pedological and agrochemical analyses. To determine the degree of soil degradation, soil samples from the degraded and nondegraded land segments have been taken, in which the content of micronutrients (NPK) and humus has been determined through universal methods, which are introduced in the methodical manual on Agro-Chemical Analyses under the editorship of B.A. Yagodin (Yagodin, et al., 1989). The degree of vegetation cover in the rangelands has been determined through accounting the quantitative and qualitative indices of plants species composition per $1 \mathrm{~m}^{2}$ (Tovmasyan, 2015). The three-year indices of livestock, plant and fruit growing activities have been provided by the community municipality (http:// findarmenia.org/, RA Kotayk region in numbers, 2017), while the qualitative and quantitative descriptive indices of soils were found in the Atlas of Soils of the Republic of Armenia (Atlas of Soils of the Republic of Armenia, 1990).

\section{Results and discussions}

The results of the investigations have disclosed that the community lands continuously suffer from landslides and erosion processes, which strongly affect the agricultural activities resulting in the deterioration of soil fertility, yearly decrease in the yield capacity of the crops and orchards cultivated in small areas, degradation of the rangeland areas and in the abrupt reduction of animal productivity. According to the data registered in the Voghjaberd municipality and the surveys conducted among the population, the average annual cow milk productivity in recent years hasn't exceeded $1900 \mathrm{~L}$ (totally 72 cows are kept in the community), the sheep wool production has made $1.8 \mathrm{~kg} /$ year, while the poultry egg production capacity -187 items per year, which is mainly related to the lack of sustainable forage base and insufficient interest of the farmers towards the mentioned branch.

The stated circumstances have fundamentally deteriorated the social and economic state of the community population paving way for emigration. Only within 2010-2017 years, 28 families emigrated from the community (105 residents totally); 21 families left to settle down in other residences of the Abovyan province with more favorable conditions, while 7 families resided in the provinces of Masis (2 families), Artashat (3 families) and Ararat (2 families).

The community land areas (totally 2360 ha lands, including ploughlands, grasslands and pastures) currently have low productivity level and when comparing them with the indices recorded upon the land surveys conducted in the 90 s of the 20th century (Hayrapetyan, 2000), it can be stated that there were brown soil types with 3-4.5\% humus content, the soil reaction was from weakly alkaline to average alkaline ( $p H-7.4-8.5)$, where the content of easily hydrolyzed nitrogen made $3.2-4.2 \mathrm{mg}$ in $100 \mathrm{~g}$ soil, the affordable phosphorus and potassium content in $100 \mathrm{~g}$ soil was 5.9-6.9 $\mathrm{mg}$ and 32-42 $\mathrm{mg}$ respectively, that is, the soils were poorly provided with nitrogen, averagely and poorly provided with phosphorus, while they were rather rich in potassium (Table 1).

Upon the data of Table 1 the study results conducted in 2019 are introduced which indicate that the content of humus and mobile nutrients got reduced. The humus content decreased in $0.5 \%$, while out of the mobile nutrients, the nitrogen content in $100 \mathrm{~g}$ ploughland decreased in $0.6 \mathrm{mg}$, phosphorus content - by $1.1 \mathrm{mg}$, and the potassium content - by $4.0 \mathrm{mg}$. This is mainly due to the degradation degree of the agricultural lands in the community, which, as it has been already mentioned, is the consequence of landslides, particularly erosion of arable lands, improper soil cultivation and the overcrowded exploitation of pastures (especially near-village ones) without any rotational grazing. 
Table 1. The agrochemical indicators of the brown soils in Voghjaberd community*

\begin{tabular}{|c|c|c|c|c|c|c|c|c|c|c|}
\hline \multirow{3}{*}{ Land areas } & \multicolumn{5}{|c|}{ The data of the RA Atlas, 1990} & \multicolumn{5}{|c|}{ The data for 2019} \\
\hline & \multirow{2}{*}{$\begin{array}{c}\text { Humus, } \\
\%\end{array}$} & \multirow{2}{*}{$p H$} & \multicolumn{3}{|c|}{ Mobile nutrients } & \multirow{2}{*}{$\begin{array}{c}\text { Humus, } \\
\%\end{array}$} & \multirow{2}{*}{$p H$} & \multicolumn{3}{|c|}{ Mobile nutrients } \\
\hline & & & $N$ & $\mathrm{P}_{2} \mathrm{O}_{5}$ & $\mathrm{~K}_{2} \mathrm{O}$ & & & $N$ & $\mathrm{P}_{2} \mathrm{O}_{5}$ & $\mathrm{~K}_{2} \mathrm{O}$ \\
\hline Ploughlands & 3.95 & 7.9 & 4.2 & 6.0 & 37.0 & 3.45 & 8.4 & 3.6 & 4.9 & 33.0 \\
\hline Grasslands & - & - & - & - & - & 3.80 & 8.2 & 4.0 & 5.0 & 34.0 \\
\hline Pastures & - & - & - & - & - & 3.90 & 8.0 & 3.7 & 5.1 & 34.0 \\
\hline
\end{tabular}

The community ploughlands and homestead lands are located in the slopes, where the upper fertile land strata are swept and moved away under the impact of atmospheric precipitations, particularly under that of heavy rainfall, which significantly affect the content of humus and affordable nutrients in the soil (Table 2).

The community lands are mainly of light brown type, while in the Abovyan province the soils, most subjected to mid and high erosion (49,8\%), occupy the overwhelming land territory along with other soil types.

The data of Table 2 show that $97.2 \%$ lands of Voghjaberd community are brown soils, $68.7 \%$ of which are averagely and strongly eroded, while the pasture areas near the community occupy $2.8 \%$ or 66 hectare land area among the overall community lands and only about $39.6 \%$ is strongly degraded.

The relatively lower content of humus and nutrients in the soil (as compared to the same indices recorded in 90 s of the

Table 2. Erosion rate of soils in the Abovyan province and Voghjaberd community, \%*

\begin{tabular}{|l|c|c|c|}
\hline \multicolumn{1}{|c|}{ Soil types } & $\begin{array}{c}\text { Area, } \\
\text { thousand } \\
\text { ha }\end{array}$ & \multicolumn{2}{|c|}{$\begin{array}{c}\text { Averagely and strongly } \\
\text { eroded }\end{array}$} \\
\hline & $\begin{array}{c}\text { Abovyan } \\
\text { province }\end{array}$ & $\begin{array}{c}\text { Voghjaberd } \\
\text { community }\end{array}$ \\
\hline Mountain-Meadow & 19.3 & 10.0 & - \\
\hline Meadow-Steppe & 5.5 & 9.1 & - \\
\hline Black soils & 18.0 & 13.1 & - \\
\hline Brown soils & 31.1 & 49.8 & 68.7 \\
\hline $\begin{array}{l}\text { Semi-Desert gray } \\
\text { soils }\end{array}$ & 1.0 & 35.7 & 39.6 \\
\hline
\end{tabular}

20th century) is related to the afore stated circumstances. The decrease in the content of nutrients and particularly in that of humus, has surely affected the yield capacity of the agricultural crops cultivated in the community when comparing it with the similar average indices in the region and with those estimated in the community for the previous years (Table 3).

Table 3. The yield capacity indices of the crops and orchards cultivated in Voghjaberd community $(2017-2019)^{*}$

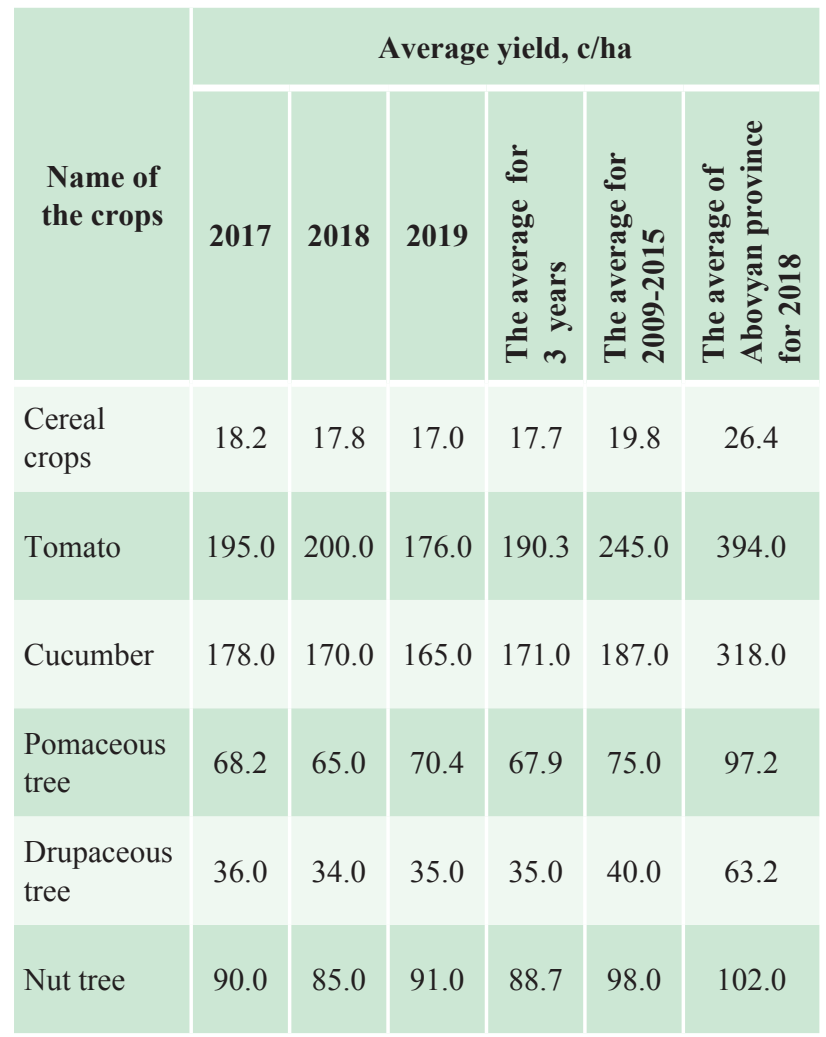

*Composed by the authors. 
So, if we compare the average data retrieved throughout the last three years on the yield capacity of agricultural crops and orchards (pomaceous, drupaceous and nut trees) of Voghjaberd community with the similar indices of the same community recorded in the previous years (2009-2015) and with those of the Abovyan province on the whole, it becomes vivid, that the yield capacity of the crops cultivated in the community is yearly decreasing, recording 15.2-24.0\% less indices than those observed for 2009-2015 in the same community; moreover, they were much lower than the average analogous indices throughout the whole region (Agriculture in the Republic of Armenia in 2011-2015, 2016, Socio-Economic Development Program of the RA Kotayk Region for 2011-2014, 2010). If the yield capacity of the community cereal crops per hectare made about 20.0 centner, that of tomato - 245.0 centner and cucumber - 187.0 centner, then in Abovyan province their average yield capacity made $26.4 \mathrm{c} / \mathrm{ha}$, $394.0 \mathrm{c} /$ ha and $318.0 \mathrm{c} / \mathrm{ha}$ respectively.

Low yield capacity indicators have been registered in the orchards as well, where according to the overyear average data, the pomaceous trees have provided $75 \mathrm{c} /$ ha yield, drupaceous ones $-40.0 \mathrm{c} / \mathrm{ha}$ and the nut trees $-98.0 \mathrm{c} / \mathrm{ha}$ yield, which is less than the average of the region by $22.2 \mathrm{c} / \mathrm{ha}, 23.2 \mathrm{c} / \mathrm{ha}$ and $4.0 \mathrm{c} /$ ha respectively. Such a low level of yield capacity in Voghjaberd community is related not only to low soil fertility, lack of scientifically justified fertilization norms and incomplete agricultural measures on the whole, but also to the adverse effects of natural hazards (landslides, erosion). Hence, if no preventive measures are taken in this respect, this catastrophic situation which reigns over the community for already 35 years can exacerbate even more and more.

As it has been already mentioned, $2.0 \%$ of the overall land fund of the community or 66 ha land areas are semi-desert gray soils. These soil types are distinguished by natural low fertility, contain very little amount of organic matters and affordable nutrients (NPK) required by the plants.

These soils are mainly located in the pasture areas of the cummunity, particularly in near-village territories, where the soils are very much prone to erosion and have been almost defoliated due to the natural sparse vegetation, as well as to the overgrazing by animals. There are only 112-180 plants per $1 \mathrm{~m}^{2}$ in these lands, which don't have any significant role in the prevention and mitigation of soil erosion. Grass growing in these land areas, especially with the seeds of perennial plants (sainfoin, fescue grass, cocksfoot, ryegrass, etc.) with $25-30 \mathrm{~kg} /$ ha seeding rate, as well as fertilization with at least $2 \mathrm{t} /$ ha dosage of biohumus or organomix organic fertilizers is a vital need, which will reclaim the agro-meliorative state of those soils and serve as a most efficient means for the further prevention or mitigation of soil erosion.

Taking into account the low level of yield capacity of crops and fruit trees grown in the lands of Voghjaberd community, which is mainly due to natural (landslide and erosion) and somewhat to anthropogenic factors, we have tried to conduct an economic calculations on the losses the community residents suffer when cultivating this or that crop or fruit tree variety in the landslide-prone and eroded land areas.

In this respect, the calculations have been carried out for one hectare land area by comparing the yield amount harvested from the landslide and eroded lands with that of harvested from landslide-free and non-eroded land area. Besides, as to the information provided by the farm owners, in both places the crop sowing, cultivation and fertilization activities were implemented upon the same agricultural rules. The calculations have been conducted for cereal crops (winter wheat), tomato and cucumber. The sell price per $1 \mathrm{~kg}$ of cereal has been assumed at $150 \mathrm{AMD}$, while that of tomato and cucumber - $100 \mathrm{drams} / \mathrm{kg}$ each. Through the difference of harvested yield amount and its cost price the attributable profits and losses have been estimated, where the cost of expenses is also included.

The yield capacity indices and the yield prices (including the labor and fertilization expenses) for winter wheat, tomato and cucumber cultivated in the landslide and eroded land areas have indicated that everywhere in the mentioned areas lower yield, and therefore, lower-price product has been received as compared to the same indices of the crops cultivated in the landslide-free and non-eroded areas.

The calculations have shown that the winter wheat cultivated in favorable soil conditions has provided $9.5 \mathrm{c} / \mathrm{ha}$ yield surplus or 142.5 thousand AMD extra income against the same indices of winter wheat cultivated in unfavorable conditions (landslide and eroded areas). The same is true for tomato and cucumber, i.e., in case of favorable conditions, tomato has provided $185 \mathrm{c} /$ ha yield surplus and $1 \mathrm{mln} 850$ thousand AMD more income (against the same indices recorded in unfavorable conditions) and in case of cucumber cultivation these indices have made $85.0 \mathrm{c} / \mathrm{ha}$ and 850.0 thousand AMD respectively (Table 4). 
Table 4. The indices of economic estimation for the yield received from the crops of Voghjaberd community*

\begin{tabular}{|c|c|c|c|c|c|c|}
\hline & \multirow{2}{*}{$\begin{array}{c}\text { Crops } \\
\text { Landslide hazard } \\
\text { and eroded area }\end{array}$} & \multicolumn{2}{|c|}{$\begin{array}{l}\text { Yield, } \\
\text { c/ha }\end{array}$} & \multicolumn{2}{|c|}{$\begin{array}{l}\text { Yield price, } \\
\text { thousand AMD }\end{array}$} & \multirow{2}{*}{$\begin{array}{c}\text { Yield cost } \\
\text { difference, } \\
\text { thousand, } \\
\text { AMD }\end{array}$} \\
\hline & & $\begin{array}{c}\text { Landslide } \\
\text { hazard and } \\
\text { eroded area }\end{array}$ & $\begin{array}{l}\text { Landslide-free } \\
\text { and non-eroded } \\
\text { area }\end{array}$ & $\begin{array}{c}\text { Landslide } \\
\text { hazard and } \\
\text { eroded area }\end{array}$ & $\begin{array}{c}\text { Landslide-free } \\
\text { and non-eroded } \\
\text { area }\end{array}$ & \\
\hline 1 & Winter wheat & 17.5 & 27.0 & 262.5 & 405.0 & 142.5 \\
\hline 2 & Tomato & 205.0 & 390.0 & 2050.0 & 3900.0 & 1850.0 \\
\hline 3 & Cucumber & 190.0 & 275.0 & 1900.0 & 2750.0 & 850.0 \\
\hline
\end{tabular}

The economic estimations have testified that the landslide and erosion processes adversely affect the ecological state of Voghjaberd community, reduce the productivity of agroecosystems resulting in deterioration of the socio-economic conditions of the population living and working in the mentioned community, hence, promoting emigration.

\section{Conclusion}

Based on the conducted studies and economic assessments the following conclusions can be inferred:

The balance violation and productivity decrease of agroecosystems in Voghjaberd community are mainly due to the strong landslides and erodibility of the land resources, as a result of which there are 500 ha land areas highly susceptible to landslides, 200 and 380 ha land areas averagely and low susceptible to landslides respectively. About $69 \%$ of the community lands are strongly and averagely eroded, exceeding the same index of the brown soils spread in Abovyan province in more than $10 \%$.

The economic estimations have disclosed that the winter wheat, tomato and cucumber cultivated in favorable conditions (landslide-free and non-eroded) have provided 40.2-68.5 yield surplus and much higher profitability as compared to the same indices of the mentioned crops cultivated in landslide and eroded land areas.

For combating the landslides occurring in the community it is recommended to establish anti-landslide forests both in the very landslide and in even farther territories.

To prevent erosion processes in the steep slopes of the community it is necessary to implement perennial plant seeding (sainfoin, fescue grass, cocksfoot) and fertilization activities in the arable lands and pasture areas.

\section{References}

1. Agriculture in the Republic of Armenia, 2011-2015 (2016). Yerevan, $-170 \mathrm{p}$.

2. Analyses of the Socio-Economic State in the RA Kotayk Region for 2010. Kotayk Municipality, 2011, 19 p.: http://kotayk.mtad.am/files/docs/4.pdf (accessed on 02.03 .2021 ).

3. Atlas of Soils of the Republic of Armenia (Under the Editorship of R.G. Edilyan). - Yerevan: Scientific Research institute of Soil Science and Agrochemistry, 1990, - 65 p.

4. Biodiversity of Armenia. The Fourth National Report. Yerevan, the RA Ministry of Environment, 2008, 120 p.

5. Economic Research in the Kotayk Region. European Program on Regional Development of Marzes in Armenia (REDAM), 2005, - 151 p.

6. Environment and Natural Resources in the RA, 2015. Dynamics of indices for 2011-2015. - Yerevan, 2016, - 112 p.

7. Galstyan, M.H., Mkrtchyan, A.L. (2013). Natural Resources of the RA. Teaching Manual, RA MES: ANAU - Yerevan, - $192 \mathrm{p}$.

8. Hayrapetyan, E.M. (2000). Soil Science. Textbook. Yerevan: “Asoghik", NAS, - 456 p. 
9. http://findarmenia.org/arm/armenia/kotayk (accessed on 12.03.2021).

10. RA Kotayk Region in Numbers. - Yerevan, 2017, - pp. 12-29, pp. 73-75.

11. Socio-Economic Development Program of the RA Kotayk Region for 2011-2014: (Annex to the RA Government Decree N 353-V, March 16, 2010). - Yerevan, 2010.

12. Statistical Yearbook of Armenia, 2017 - Yerevan, - pp. 298-315.
13. The Nature of Armenia.- Yerevan : Issue of Armenian Encyclopedia, 2006, - pp. 47-50.

14. Tovmasyan, G.A. (2015). Sustainable Management of Biodiversity, South Caucasus. Pastures Monitoring Manual - Yerevan "TASK” LLC, - 66 p.

15. Yagodin, B.A., Smirnov, P.M., Peterburgskiy, A.V. (1989). Agrochemistry (Under the Editorship of B.A. Yagodin). Second Issue, Sup.- M.: Agropromizdat, - 639 p. 